\title{
Early Musical Impressions from Both Sides of the Loudspeaker
}

\section{Sérgio Freire}

A B S T R A C T

A the loudspeaker and its sides sums up the spatio-temporal ruptures that started shaping aural perception in the late 19th century: on one side, the listener; on the other, sound events conveyed by phonographic products, radio and various sound-recording devices. Diverse practices as well as samples of theoretical and aesthetic thinking from the early 20th century illustrate how new media have affected the musical imagination and listening in general. vice to those events. While traditional musics strive to adapt to new production and diffusion conditions, new ideas blossom, widening and transforming musical experience on both sides of the loudspeaker.

One can easily imagine a loudspeaker separating the worlds of listener and producer in the case of live radio, but the metaphor becomes blurred when previously produced sounds come into play. But even then, be it a question of a musical record or of any sound recording whatsoever, the notion of a medium that conveys sound events seems to prevail in aural perception, which effortlessly reconstructs an original soundproducing event (not seldom a mere supposition). Appraisals of such objects not as media but as aesthetic objects per sea record and its grooves, images resulting from optical sound recording-represent exceptional cases.

I shall not deal herein with the development, up to 1950, of electro-electronic instruments, that vast topic; rather than significantly altering paradigms of musical performance and discourse, they inevitably invoke comparison with their unamplified relatives. Three specific processes-recording of music, radio broadcasting and sound recording - are tackled here. In the last two sections I discuss, in a more generic fashion, not only the impetus that the rise of new reproduction and transmission means has provided to the aesthetic-musical imagination but also the impact of such means upon the perception and conceptualization of seemingly trivial sonic facts.

\section{MUSIC ON CYLINDER AND DISC}

The technical differences-and the competition-between the phonograph (1877) and the gramophone (1887), the two most important sound-reproduction machines invented in the late 19th century, are well known: cylinder versus disc, "hilland-dale" versus "to-and-fro" grooves, play/record versus playonly functions, etc. [1]. All the same, a marketing strategy of Thomas Edison's, from a time when he was producing disc phonographs only, offers an opportunity for discussing the influence of such machines upon musical diffusion and practice from other points of view. From 1915 to 1926 Edison promoted, in Canada and the United States, a vast marketing campaign for his new diamond disc. The campaign was based on "tone tests": son Phonogh and sings-or plays Suddenly, and without warning, the tinues alone. The test is whether the audience, with eyes closed, can tell when the living artist has ceased to sing-or play. Where practicable, the lights are turned off suddenly and the artist steals from the stage, leaving the New Edison to perform its miraculous feat of Re-Creating the singer's voice-or instrumentalist's perfor-

mance-with such a perfect realism that the audience is not aware of the artist's departure until the lights are turned on [2].

Edison's intention was to demonstrate that "it was actually impossible to distinguish the singer's living voice from its recreation in the instrument" [3]. With such a strategy, relying on the equivalence of live performance and recording reproduction, Edison sought to disguise spatio-temporal disruptions brought about by the phonograph. Also implied in the marketing campaign was the illusion that musical practice would remain unchanged in the face of the new "instrument." Still, while recorded music brought about significant improvements to listeners' lives by allowing them to "play" at home at any time a huge variety of musical works, it also started threatening the musical tradition from which those works sprung. Theodor Adorno puts the conflict into enigmatic words: "If the productive force of music has expired in the phonograph records, if the latter have not produced a form through their technology, they instead transform the most recent sound of old feelings into an archaic text of knowledge to come" [4].

Music played on the phonograph or gramophone remained essentially the same for a while. The machines did not immediately give rise to either a radical change in musical discourse or a new artistic mode. They did, however, introduce musical recording into private life. "It is just because these devices bring into our homes renditions of music of a superior quality, to which the vast majority of our people are total strangers, that they are meeting with such universal acceptation" [5]. Intellectuals, in contrast, put forward other reasons:

To be able to choose the moment of a pleasure, to be able to enjoy it when it is not only desired by the mind but also required

Sérgio Freire (composer and music teacher), Rua Lapinha, 65/401, 30550-170 Belo Horizonte, Brazil. E-mail: <sfreire@musica.ufmg.br>. Translated from the Portuguese by Carlos Palombini. Translations from the German, unless otherwise stated, by S. Freire and C. Palombini. Translations from the French by C. Palombini. 
and as if already sketched by the soul and being, is to offer the greatest opportunities to the composer's intentions, for it is to allow his creatures to revive in a live environment that is not very different from the one in which they were created. The work of the musical artist-author or virtuoso-finds in recorded music the essential condition for the highest aesthetic advantage [6].

The considerable limitations of recorded music at that time (restricted frequency response, lack of spatiality, short duration) and the frozen performance that records enshrined seem to have been accepted without question by domestic listeners, many of whom owed their musical nurturance to these very limitations.

Deep changes were taking place in musical life and practice during the late 1800 s and early 1900s, and, naturally, professional musicians and composers did not welcome the relative independence that musical fruition was acquiring as regards traditional performance. "[John Philip] Souza feared the replacement of music making with passive listening" [7], and, as early as 1906, the ongoing devaluation of performance induced him to forge the phrase "canned music.” Later on, Béla Bartók reaffirmed Souza's preoccupations: "But even in that case [in which reproduced music is exactly the same as the live music] there will be an irreplaceable superiority, for which there is no substitute, of the live music over stored, canned music. This substitute is the variability of live music" [8]. Composers and artists, for their part, did not remain indifferent vis-à-vis the much desired creative potential of the new machines. A not uncommon idea was the opposition between the use of the machines for reproduction and their use in original sound production. The Hungarian artist and Bauhaus professor László Moholy-Nagy, for instance, proposed in the 1920s "from the reproduction instrument gramophone to create a productive instrument, so that, through the incision of the required series of grooves, an acoustic phenomenon with no previous acoustic existence arises" [9]. And Edgard Varèse affirmed in 1939: "Personally, for my conceptions, I need an entirely new medium of expression: a sound-producing machine (not a soundreproducing one). Today it is possible to build such a machine with only a certain amount of added research" [10]. Varèse was not referring to the gramophone in particular. Instead, he was pointing out and criticizing the development of new sound technologies that failed to fall in line with contemporary musical thinking (in this case, his own). In other words, he was critiquing the development of sound machines (disc players, sound recorders or imitative instruments) whose main function was to reproduce sounds. In reality, the technical distinction between production and reproduction had begun to be more and more blurred since the electrification of recording in the 1920s.

As legitimate as the listener's "performance" of recordings was artists' desire to make creative use of the new means. The production they dreamed of was not antithetical to reproduction. Production and reproduction could even complement each other, as when someone played the recording of a piece that had made creative use of one or another new means. The difference resides less in the function of the machine than in what the listener is offered through the loudspeaker: the documentation of a musical performance of a piece that already exists, a novel creation or something somewhere in between.

\section{RADIO}

When radio broadcasts started making their way into the daily life of a considerable part of the world population in the 1920s, private life acquired a hitherto unknown public dimension. Not only because sounds from other places started gaining admission into private homes (following telephone conversation and music recording) but above all because broadcasts, by reaching distant and distinct places at once, began grouping listeners into communities of non-neighboring members. A common agenda could be easily arranged for apparently isolated people: "The most profound change it [the radio] brought was simultaneously to privatize and structure life according to a rigorous timetable, which henceforth ruled not only the sphere of labor but that of leisure" [11]. Moreover, "[f] or the first time in history people unknown to each other who met knew what each had in all probability heard (or, later, seen) the night before" [12].

In the early 1930s, Walter Benjamin criticized the radio in the following terms: "The crucial failing of this institution has been to perpetuate the fundamental separation between practitioners and the public, a separation that is at odds with its technological basis" [13]. In fact, however, radio never really cared for effective dialogic strategies between emitter and audience. Instead, it crystallized into an omnipresent and almost completely deaf emitter, which only conducted dialogues if, when and with whom it pleased. Still in the 1930s, merchants and rulers began exploiting radio's potential for mass communication: the U.S. president in his "fireside chat"; the Nazi party after its rise to power in 1933. From 1933 to 1939, a German consortium developed and sold about 4 million units of a popular radio model, the VE 301 [14].

In radio, all power of communication rests on sound. Texts, ideas, ambiences and events are broadcast and perceived as acoustic features. Although the invisibility of the world is no novelty in human history (and the link between hearing and our defense instinct survives), the diversity of events that radio brings to pass gives rise, on the listener's side, to a powerful imagination, unconcerned with self-defense. From its inception, radio exploited music. Originally threatened, the phonographic industry soon realized that collaboration with the new medium would make for mutual profit. In radio, as in musical recordings, the absence of images of performing musicians did not essentially alter the perception of either the originating musical performance or the musical discourse conveyed. Still, music that reaches the listener's home for free, unannounced, amid other musics, in the course of various radio programs certainly imparts its scattered character upon the listening.

In Germany, radio not only affected a highly developed musical life but it also received the attention of and generated expectations from such art critics as Rudolf Arnheim and Kurt Weill. On the side of musical practice, preoccupations had to do with the possibilities of capturing and broadcasting the sounds of different ensembles and styles, each with its own characteristics of power, depth and directionality. From the late 1920 s onward, such problems were discussed inside music schools, resulting in the idea of a "radiophonic" music, directly feeding the broadcasting apparatus (and eventually leading to the electronic instrument known as the trautonium [15]).

While problems that demanded essentially technical solutions were gradually minimized or solved, radio praxis raised important conceptual issues. Arnheim wrote in 1933 that " $\mathrm{t}]$ he rediscovery of the musical note in sound and speech, the welding of music, sound and speech into a single material, is one of the greatest artistic tasks of the wireless" [16]. And he stressed the influence music might exert upon the new art:

Wireless must not take any part in enlarging the gap between music and natural unmusical sound. As a purely acoustic art, it is more closely related and connected with music than any other aural art (sound-film or theatre). Its function is to present the world to the ear, and, in the task of working up the purely formal properties of its formative 
material, music will suggest itself as a wonderful aid [17].

In a 1925 chronicle, Weill had gone even further. Criticizing a movie show in which works of "absolute film" (a 1920s German movement) had been presented, he speculated on the resources of an absolute radio art, in which "the invisibility of the whole apparatus plays an important role" [18]. "Absolute film" was silent film without script, characters or drama, just moving images animated by musical ideas, and Weill directed his criticism to the outward nature of this kind of film, in which "what should be expressed is missing: soulfulness, the inner singing" [19]. He demanded from wireless, in exchange:

What new the film has brought along: the continuous change of scenery, the simultaneity of two events, the tempo of real life and the faster-than-life tempo of satire, the marionettish truthfulness of the trickfilm and the possibility of following a line from its beginning to its transition to other forms-all this, transposed into acoustic relations, the microphone must also accomplish.... The "acoustic slow motion" must be invented, and many other things. And all of this could then lead to an absolute radio art [20].

Also foreshadowed by Weill was an enhanced palette of musical sounds:

Now, we can very well imagine that new sounds, sounds from other spheres, will join the tones and rhythms of music: calls of human and animal voices, voices of nature, the noises of winds, water, trees, and then a host of new, unheard sounds that the microphone could produce in artificial ways if sound waves were raised or lowered, superimposed or interwoven, faded out or born anew. To highlight once more the most important: such an opus should engender no atmospheric picture, no symphony of nature with as realistic as possible a use of all means available, but an absolute, soulful artwork floating above the earth. ... [21]

Though at the time of Weill's chronicle radio was still in its technical infancy, operating essentially with live broadcasts, his speculations implied an apparatus not unlike the camera (lenses plus film) for the capture and montage of sounds. And it would be precisely the possibilities of sound as recorded (on wax discs or film) that would rescue the soundplay [22] from the constraints of "a relatively haphazard and improvised structuring of dissimilarnatural, artificial, and imitative-materials" [23] and pave the way for more elaborate, purely aural creations.

\section{RECORDED SOUND}

In 1878 , in his first text about the newly invented phonograph, Edison stated that it would "undoubtedly be liberally devoted to music" [24], although he believed that its main use would reside in "letter-writing and other forms of dictation" [25]. The first two faits accomplis he cites illustrate spatio-temporal ruptures created between the sonic event and its listening:

1. The captivity of all manner of soundwaves heretofore designated as "fugitive" and their permanent retention.

2. Their reproduction with all their original characteristics at will, without the presence or consent of the original source, and after the lapse of any period of time [26].

Ten years later, in 1888 , the perfected phonograph was reintroduced as an office machine. One of its novelties was a cylinder of re-recordable wax (the earlier model employed a recordable tinfoil sheet). Yet the new phonograph still did not meet with success. Attempts to increase popularity and profitability would fail to be had until a mechanism that exchanged musical or humorous numbers for coins was adapted. Ever since, the economic prospects of the phonograph, like those of its frontal and more successful rival, the gramophone, have become attached to musical reproduction. Nevertheless, Edison kept launching phonographs with domestic-recording capabilities until 1912, when he abandoned the recordable cylinder for a disc model, a move that precluded excursions into dilettante sound recording. Ordinary users would have to await the popularization of magnetic tape recorders, in the second half of the 20 th century, to relish domestic recording again.

Electromagnetic sound recording originated late in the 19th century with the Danish physicist Valdemar Poulsen's Telegraphone. Its medium evolved from the use of steel wire to the use of magnetic tape. Only in 1949, when they acquired the capability of rendering sounds from 20 to $20,000 \mathrm{~Hz}$, did tape recorders begin to be used in professional studios [27]. And even before the development of machines with multitrack recording capabilities, tape recording permitted a double operation, long known to filmmakers, that was explored in new modalities of composition as well as in the correcting/editing of musical recordings: cutting and splicing [28].

And it was precisely with sound film that, in 1930, the German director Walter Ruttmann produced Weekend, a soundplay on optical film, a "movie without images," lasting 11 minutes, 10 seconds. Amazing in this piece, besides the quality of the recording (thought to be lost until 1978, when a tape was found), is, above all, the montage of sound takes, structured into five scenes. In 1929 Ruttmann had already sought to come to terms with this acoustic art in Neue Gestaltung von Tonfilm und
Rundfunk: Programm einer photographsichen Hörkunst, concluding as follows:

The technique of sound film brings the possibility [of a montage free from all fortuities and under the creator's total responsibility].

By sound-film we should not understand here the combination of optical and acoustic photography, but simply the procedure of photographing audible phenomena in a non-stylized manner, with the inclusion of their specific spatial characteristics. Once the photography of sound occurs by exposure of film to light, acoustic montage disposes of the same possibilities as the film cutting.

Every audible in the entire world becomes material. This infinite material is now shapeable into new sense according to the laws of time and space. For not only rhythm and dynamics shall serve the compositional will of this new aural art, but also the space with the whole gamut of sound diversity conditioned by it.

Hence the way is open to a perfect new acoustic art-new by its means and by its effect.

In its application, this art inherits, enlivens, and widens the fields of music and soundplay.

To its own valuing, it employs, first of all: wireless and the disc [29].

Unfortunately, Ruttmann did not undertake any more experiments in acoustic montage. Instead, he continued to shoot films and later started collaborating with the Nazis, even portraying, in Deutsche Panzer (1940), the occupation of Paris by German tanks. Ruttmann died in 1941.

After the war, telecommunications engineer Pierre Schaeffer, who had broadcast the liberation of Paris from the Studio d'Essai of the Radiodiffusion $\mathrm{Na}$ tionale, took a decisive step toward musique concrète, a new mode of purely aural art based on the production and manipulation of recordings of any sounds whatsoever. In the early 1940s, Schaeffer had already issued a warning [30] against a totally preplanned approach to this immense unexplored field, thus anticipating some of the preoccupations he would later deal with in his recherche musicale.

To someone who approaches writing for radio or cinema for the first time, everything seems possible: the instrument lending itself-so he thinks-to everything he may take the trouble of conceiving, his only difficulty seems to be that of choosing.... But how few of them will be retranscribed on disc or film? When it comes to the découpage, the most beautiful ideas prove unfeasible while an insignificant detail, on the contrary, takes on an unexpected importance. ... Such is the revolution that cinema and radio bring to our habits of thought and expression. Man is no longer alone in seeing only what he wants to see, in hearing only what he wants to hear. He has a partner. Someone has seen and heard in his place, he 
discovers it with enthusiasm or disappointment [31].

\section{BETWEEN SENSATION AND CONCEPT}

\section{Schaeffer continues as follows:}

He is like someone who would have discovered the dictionary of a new language, and this dictionary is not a true dictionary, for there are blanks in one or the other column, and such blanks do not match. .. . You can see that our dictionary includes voids, that translations from and into [32] one or the other language are not always possible, for it is quite clear that the reverse is true [33].

Experiencing sensations for which no established concept exists is not the exclusive appanage of those who make their way towards the "relay-arts," as Schaeffer [34] calls cinema and radio; it is, on the contrary, the hallmark of the majority of artistic expressions. What is new about the relay-arts is that the objects to be aesthetically enjoyed are no longer essentially authorial creations but may even consist in different aspects of nature itself. In an attempt to describe objectively a sensorial reality or even to imagine new artistic modes, many texts from this period make explicit reference to alphabets, dictionaries and lacunae. The conflict between perception and conceptualization becomes apparent in distinct fashions: either the concepts do not suffice to encompass the perceived fact (the listener does not recognize what is coming from the other side of the loudspeaker) or the conceptualization itself, in agreement with its historical situation, demands new forms of artistic perception (the artist/listener creates/requires aesthetic novelties arriving from the other side of the loudspeaker).

In his 1925 article on absolute radio art Weill asked: "But how shall melody come to fulfillment in an absolute aural art, which is not called music? What noises or sounds could replace melody in such perfect measure as to be able to fill a time span with the most intense experience?" [35] Dziga Vertov, the Russian film director who, from 1916 onwards, made "the first known attempts at building up a new work by combination and montage of preexistent sound recordings" [36], subsequently made the experiment of describing the sounds of a sawmill. Having verified the insufficiency of writing for notating the generality of sound events, he concluded: "In addition to vowels and consonants, there were different melodies to hear, with motifs hardly susceptible to reproduction. We would have to reproduce them with some new musical sign.
Yet, musical signs that corresponded to natural sounds did not exist" [37].

On the part of composers, this lack had been noted as early as 1916: "Our musical alphabet has got to grow richer" [38], Varèse used to say. And in 1928 the Czech artist and theoretician Karel Teige, in his Druhy manifest poetismu (Second Manifesto of Poetism), made clear the demand and the need for new aesthetic procedures attuned to the new scientific discoveries:

We have therefore pursued not only a renewal, but rather the invention of new compositions, because new worlds, new realms, new responses, the echo of the subconscious and the imagination of the hyperconscious, the infrared and the ultraviolet, unexplored domains and unfilled blanks in the map of aesthetics attract our interest and challenge the creative ingenuity to experimentation [39].

\section{Teige continues:}

We have renounced the historical forms of painting and verse making. Having renounced the dictionary of concepts, we seized the dictionary of reality. We have indicated the possibility of a wordless poem, the possibility of making poetry with a much more reliable material, which is constructive and scientifically controlled: to make poetry with color, form, light, movement, sound, odor, energy [40]

Teige was probably unable to foresee or experience the fact that the will to creatively employ the new technological means would have to be balanced with new modes of perceiving reality that these very means afforded. Tackling the role of the camera in cinema in his 1935 essay on the technical reproducibility of the artwork, Walter Benjamin compared such new perceptions to the unconscious experience:

Here the camera intervenes with its many resources-its lowerings and liftings, its interruptions and isolations, its stretchings and accelerations, its enlargements and reductions. Through the camera, we experience for the first time the optical unconscious as, through psychoanalysis, we experience the pulsional unconscious [ Treibhart-Unbewußt]. Moreover, the connections between both are the most intimate. For the manifold aspects of reality that the registering apparatus can capture, rest, in the majority of cases, exclusively outside a normal spectrum of sensorial perception [41].

\section{CONCLUding Remarks}

The differences between a sound event and its representation, the autonomy of such a representation, and the possibilities of manipulating and combining representations in various ways suggest a vast and unexplored perceptive-cognitive field. Looking into the subsequent development of various means of communication-musical recordings, radio broadcasts, sound recording-we come to the conclusion that the field has been only partially if at all explored. New, purely aural, artistic modalities have failed to reach the cultural and economic status attained by cinema. They remain as fringe activities, playing a relevant role only on specific radio stations and in particular musical niches. The development of television contributed to the crystallization of the audiovisual model of production, to the detriment of the purely audible. Moreover, the sheer quantity and diversity of musical recordings available to presentday listeners is certainly more relevant to them than a "productive"- as opposed to "reproductive"-use of the new means. Finally, the live performance paradigm prevails, even for musical works that are totally dependent on new technologies for their creation and that find in the disc their preferred means of diffusion.

Yet the influences that the spatiotemporal cleavages created between a sonic fact and its audition exert upon musical imagination keep acting, consciously or subliminally, on each listener, creative artists included. The whole conflict between (and the whole shuffling of) the notions of event and representation and of work and fruition indicate a new aesthetic experience for the ear, one in which listeners are called upon to participate more actively in the definition of their object of contemplation. This new situation, which with the image of the two sides of the loudspeaker I have sought to emblematize, is already detectable in the following excerpt from a 24-year-old Adorno: "The turntable of the talking machines is comparable to the potter's wheel: a tone-mass [42] is formed upon them both, and for each the material is preexisting. But the finished tone/clay container that is produced in this manner remains empty. It is only filled by the hearer" [43].

\section{Acknowledgments}

The present article results from research towards my dissertation (Pontifical Catholic University of São Paulo) conducted from November 2001 to July 2002 in Basel under the generous sponsorship of the Office for the Development of Higher Education Personnel (CAPES), a body of the Brazilian Ministry of Education (MEC). Stephen Hinton pointed me to the published English translation of Weill's "Möglichkeiten absoluter Radiokunst," which Diana Diskin photocopied and posted from the United States. Cathy Cox provided copies of the published English translations of Adorno's "Die Form der Schallplatte" and "Nadelkurven." To all of them, my heartfelt thanks.

\section{References and Notes}

1. See, among others, O. Read and W. Welch, From Tin Foil to Stereo: Evolution of the Phonograph (New York: 
Macmillan, 1977), and M. Chanan, Repeated Takes: A Short History of Recording and Its Effects on Music (London and New York: Verso, 1995).

2. J. Harvith and S.E. Harvith, Edison, Musicians, and the Phonograph (New York, Westport and London Greenwood Press, 1987) p. 12, where the quotation remits to the following note on p. 20: "From a lette drafted by the Federal Advertising Agency, March 2 1920, and sent on Edison company letterhead to James Montgomerv Flagg, in the files of the Edison National Historic Site."

3. From "Demonstrate New Edison Invention," Boston Journal (19 November 1915), cited by E. Thompson, "Machines, Music and the Quest for Fidelity: Marketing the Edison Phonograph in America, 1877-1925," Musical Quarterly 79, No. 1 (1995) p. 132

4. T.W. Adorno, "The Form of the Phonograph Record," T.E. Levin, trans., October 55 (Winter 1990) pp. 59-60. Originally published in 1934 as "Die Form der Schallplatte.

5. See Thompson [3] p. 140, where the quotation re mits to the following note: "The Menace of Mechanical Music: Some of the Replies Evoked by Mr. Sousa's Article," Appleton's 8 (Nov. 1906) p. 639. The author of those lines is referred to as "a responden to Sousa's editorial" in Thompson's article (p. 139)

6. P. Valéry, "La conquête de l'ubiquité," in Oeuvres II (Paris: Gallimard, 1960) p. 1286. Originally published in 1928

7. See Thompson [3] p. 139.

8. B. Bartók, "Mechanical Music," in B. Suchoff, ed. Béla Bartók Essays (New York: St. Martin's Press, 1976) p. 298. Essay originally published in Hungarian as "A gépzene" in Szép szóii, No. 11 (1937).

9. Quoted in S. Amzoll, "Die Republik lauscht: Faszination früher künstlerischer Radiophonie," Neue Zeitschrift für Musik 155, No. 1, (1994) p. 31.

10. E. Varèse, "Music as an Art-Science" (from a lecture given at the University of Southern California, 1939), in E. Schwartz and B. Childs, eds., Contemporary Composers on Contemporary Music (New York: Da Capo Press, 1978) p. 200

11. E. Hobsbawm, The Age of Extremes: A History of the World, 1914-1991 (New York: Vintage Books, 1996) p. 196. First published in 1994.

12. See Hobsbawm [11] p. 196

13. W. Benjamin, "Reflections on Radio," in M.W. Jennings, H. Eiland and G. Smith, eds., Selected Writ ings of Walter Benjamin II: 1927-1934, R. Livingstone trans. (Cambridge and London: Belknap Press of Harvard Univ. Press, 1999) p. 543. Written in 1931 as "Reflexionen zum Rundfunk." Benjamin worked strenuously in and on radio: theory, script and production. Yet, if he virtually ignores radio in "Das Kunstwerk im Zeitalter seiner technischen Reproduzierbarkeit," this is due more to political reasons than to technical deficiencies.

14. The acronym derives from "People's Receiver" (Volksempfänger) and "30 January" (30.1), the date the National Socialists seized power. For additional information, see A. Diller, "Rundfunk und Fernsehen: Geschichte," in L. Finscher, ed., Die Musik in Geschichte und Gegenwart: Allgemeine Enzyklopädie der Musik, Vol. 8 (Kassel, Basel, London, New York and Prague: Bärenreiter; Weimar and Stuttgart: Metzler, 1998) pp. 611-617

15. On the subject of the trautonium and its relationship to radio, see A. Ruchskowski, Elektronische Klänge und musikalische Entdeckungen (Stuttgart: Philipp Reklam, 1998) pp. 57-74; E. Ungeheuer, "Elektroakustische Musik: Technik- und Kulturgeschichte ca. 1900 bis 1950: Das Trautonium," in Finscher, ed. [14] Vol. 2, pp. 1737-1739.

16. R. Arnheim, Radio (London: Faber and Faber 1936) pp. 30-31. Translated by M. Ludwig and $\mathrm{H}$. Read. Reprint edition (Salem: Aver, 1986). Written in 1933 as "Der Rundfunk sucht seine Form."

17. Arnheim [16] p. 32
18. K. Weill, "Möglichkeiten absoluter Radiokunst," in D. Drew, ed Kurt Weill: Ausgewuählte Schriften (Frankfurt: Suhrkamp, 1975) p. 129. Originally published 28 June 1925. In translating excerpts from this article from the German, we have taken account of an English translation. See D. Farneth, with E. Juchem and D. Stein, eds., Kurt Weill: A Life in Pictures and Documents (Woodstock and New York: Overlook Press, 2000) pp. 282-283.

19. See Weill [18] p. 129

20. See Weill [18] p. 130

21. See Weill [18] pp. 130-131.

22. I use the term "soundplay" in this article to translate the German "Hörspiel."

23. W. Ruttmann, "Neue Gestaltung von Tonfilm und Rundfunk: Programm einer photographischen Hörkunst," in J. Goergen, Massenmedien und Kommunikation (Walter Ruttmanns Tonmontagen als Ars Acustica), No. 89 (1994) p. 25. Originally published in Film-Kurier 11, No. 255 (26 October 1929).

24. T. Edison, "The Phonograph and Its Future," North American Review 126, No. 262 (1878) p. 533.

25. See Edison [24] p. 531.

26. See Edison [24] p. 530

27. See H. Hiebel, ed., Kleine Medienchronik: von den ersten Schriftzeichen zum Mikrochip (Munich: Beck, 1997) p. 166

28. Film sound recording also had to face, from it commencement, problems that hardly existed in musical recording: continuity, control of perspective and changes of distance and ambience.

29. See Ruttmann [23] pp. 25-26.

30. In "Esthétique et technique des arts-relais," excerpt from an unpublished 1941 draft, printed in S. Brunet, ed., Pierre Schaeffer: de la musique concrète à la musique même, triple special issue of Revue musical Nos. 303-305 (1977) pp. 19-23

31. See Schaeffer in Brunet, ed. [30] pp. 20-21.

32. Schaeffer employs the terms theme and version, rendered herein as "translation from" and "translation into, with reference to each column of that conjectural dictionary. Such terms reappear in his Traite des objets musicaux (Paris: Seuil, 1966) in connection with traditional pieces of music (pp. 86-87) as well as to sonority in general (pp. 390-394).

33. See Schaeffer in Brunet, ed. [30] p. 21

34. Schaeffer may have borrowed the term arts-relais from Valéry, who, in February 1937, presented the literary art as "that which works chiefly by relay, rather than by direct sensation." See P. Valéry, "De l'enseignement de la poétique au Collège de France," in Introduction à la poétique (Paris: Gallimard, 1938) p. 14

35. See Weill [18] p. 132

36. See Goergen [23] p. 14

37. D. Vertov, conference of 5 April 1935, manuscript deposited in the Archive of the Austrian Film Museum, Vienna, cited by Goergen [23] p. 14.

38. E. Varèse, Écrits (Paris: Christian Bourgois, 1983) p. 23. From a New York interview in March 1916, ac cording to Ecrits, originally published in the New York Telegraph. L. Hirbour casts doubt on this source in "Bibliographie et discographie de Varèse"; see F. Ouellette, Edgard Varèse, Rev. Ed. (Paris: Christian Bourgois, 1989) p. 256

39. K. Teige, "Manifest des Poetismus," in Liquiderung der "Kunst": Analysen, Manifeste (Frankfurt am Main Suhrkamp, 1968) pp. 92-93. Translated into German from the Czech by Paul Kruntorad. Originally published as "Druhy manifest poetismu," Revue devetsilu 1, No. 7 (1928).

40. See Teige [39] p. 102

41. W. Benjamin, "Das Kunstwerk im Zeitalter seiner technischen Reproduzierbarkeit," in Walter Benjamin
Gesammelte Schriften, Vol. I.2 (Frankfurt: Suhrkamp, 1974) p. 461

42. Levin (the translator) observes that "Adorno here plays upon the untranslatable polyvalence of Ton which in German means both 'sound' or 'tone' and also 'clav.' A Ton-Masse is thus a quantity or mass both of acoustic and of argillaceous material."

43. T.W. Adorno, "The Curves of the Needle," Octo ber $\mathbf{5 5}$ (Winter 1990) p. 55. Translated by T.E. Levin Originally written in 1927 and published in 1928 as "Nadelkurven."

\section{Bibliography}

Baker, R.S. "New Music for an Old World: Dr. Thaddeus Cahill's Dynamophone, an Extraordinary Electrical Invention for Producing Scientifically Perfect Music," McClure's Magazine 27, No. 3, 291-301 (1906).

Bever, R. "Das Problem der kommenden Musik," Die Musik 20, No. 12, 861-866 (1928)

Blomann, K.H., and Sielecki, F., eds. Hören: eine vernachlässigte Kunst? (Hofheim: Wolke, 1997).

Chion, M. Le son au cinéma (Paris: Cahiers du Cinéma, 1985).

Edison, T. "The Perfected Phonograph," The Manu facturer and Builder 20, No. 6, 128-129 (June 1888).

Handzo, S. "A Narrative Glossary of Film Sound Technology," in E. Weis and J. Belton, eds. Film Sound: Theory and Practice (New York: Columbia Univ. Press, 1985) pp. 383-426.

Kahn, D. Noise, Water, Meat: A History of Sound in the Arts (Cambridge and London: MIT Press, 1999).

Kahn, D., and Whitehead, G., eds. Wireless Imagination: Sound, Radio, and the Avant-Garde (Cambridge and London: MIT Press, 1992).

Roads, C. "Early Electronic Music Instruments: Time Line 1899-1950," Computer Music Journal 20, No. 3 20-23 (1996).

Schaeffer, P. À la recherche d'une musique concrète (Paris: Seuil, 1952)

Schoenberg, A. "Mechanical Musical Instruments," in L. Stein, ed. Style and Idea: Selected Writings of Arnold Schoenberg (London: Faber and Faber, 1975) 326-330. Originally published in 1926 as "Mechanische Musikinstrumente."

Szendy, P., ed. Les cahiers de l'Ircam: L'écoute (Paris Harmattan/Ircam, 2000)

Thomas, J.C., ed. Oür, Entendre, Ecouter, Comprendre après Schaeffer (Paris: Ina/Buchet-Chastel, 1999).

Weill, Kurt. "Zur Psychologie der funkischen Programmbildung," in D. Drew, ed., Kurt Weill: Aus gewählte Schriften (Frankfurt: Suhrkamp, 1975) pp. 97-101. Originally published 14 November 1926.

Weill, Kurt. "Der Rundfunk und die Umschichtung des Musiklebens," in D. Drew, ed. Kurt Weill: Au gewählte Schriften (Frankfurt: Suhrkamp, 1975) pp. 111-116. Originally published 13 April 1928

Weill, Kurt. "Der Rundfunk und die neue Musik," in D. Drew, ed., Kurt Weill: Ausgewählte Schriften (Frankfurt: Suhrkamp, 1975) pp. 135-138. Originally published 25 January 1929.

Manuscript received 14 January 2003

Sérgio Freire has studied composition and electroacoustic music in Brazil, Holland and Switzerland. A composer and performer of electroacoustic music, he teaches in the Music School of the Federal University of Minas Gerais, Belo Horizonte, Brazil. 